Article

\title{
In Vitro Antioxidant, Anti-Diabetes, Anti-Dementia, and Inflammation Inhibitory Effect of Trametes pubescens Fruiting Body Extracts
}

\author{
Kyung Hoan Im, Trung Kien Nguyen, Jaehyuk Choi and Tae Soo Lee * \\ Division of Life Sciences, Incheon National University, (Songdo-dong) 119 Academy-ro, Yeonsu-gu, \\ Incheon 406-772, Korea; khim61@inu.ac.kr (K.H.I.); tknguyen@inu.ac.kr (T.K.N.); jaehyukc@inu.ac.kr (J.C.) \\ * Correspondence: tslee@incheon.ac.kr; Tel.: +82-32-835-4617 \\ Academic Editor: Derek J. McPhee \\ Received: 19 February 2016; Accepted: 9 May 2016; Published: 16 May 2016
}

\begin{abstract}
Trametes pubescens, white rot fungus, has been used for folk medicine in Asian countries to treat ailments such as cancer and gastrointestinal diseases. This study was initiated to evaluate the in vitro antioxidant, anti-diabetes, anti-dementia, and anti-inflammatory activities of T. pubescens fruiting bodies. The 1,1-diphenyl-2-picryl-hydrazyl (DPPH) free radical scavenging activities of T. pubescens methanol (ME) and hot water (HWE) extracts $(2.0 \mathrm{mg} / \mathrm{mL})$ were comparable to butylated hydroxytoluene (BHT), the positive control. However, the chelating effects of ME and HWE were significantly higher than that of BHT. The HWE $(6 \mathrm{mg} / \mathrm{mL})$ also showed comparable reducing power to BHT. Eleven phenol compounds were detected by high performance liquid chromatography (HPLC) analysis. The $\alpha$-amylase and $\alpha$-glucosidase inhibitory activities of the ME and HWE of the mushroom were lower than Acarbose, the standard reference; however, the inhibitory effects of the mushroom extracts at $2.0 \mathrm{mg} / \mathrm{mL}$ were moderate. The acetylcholinesterase (AChE) and butyrylcholinesterase (BChE) inhibitory effects of ME and HWE were moderate and comparable with galanthamine, the standard drug to treat early stages of Alzheimer's disease (AD). The ME had a neuroprotective effect against glutamate-induced PC-12 cell cytotoxicity at the concentration range of $2-40 \mu \mathrm{g} / \mathrm{mL}$. The mushroom extracts also showed inflammation inhibitory activities such as production of nitric oxide (NO) and expression of inducible nitric oxide synthase (iNOS) in lipopolysaccharide (LPS)-induced murine macrophage-like cell lines (RAW 264.7) and significantly suppressed the carrageenan-induced rat paw-edema. Therefore, fruiting body extracts of T. pubescens demonstrated antioxidant related anti-diabetes, anti-dementia and anti-inflammatory activities.
\end{abstract}

Keywords: anti-diabetes; anti-inflammation; antioxidant; anti-dementia; Trametes pubescens

\section{Introduction}

Mitochondria are the main organelles producing energy of the cell in the form of adenosine triphosphate (ATP) by oxidative phosphorylation (OXPHOS), and are also involved in signal transduction of cellular metabolic pathways. In addition to these activities, mitochondria play crucial roles for generating reactive oxygen species (ROS), the regulation of intracellular $\mathrm{Ca}^{2+}$, and programmed cell death (apoptosis). Although intracellular enzymes and other antioxidant defense system keep ROS concentrations under control, excessively produced ROS from mitochondria due to the incomplete processing of oxygen and free electrons released from electron transport chain (ETC) during OXPHOS were associated with chronic diseases such as diabetes, cardiovascular, ageing, inflammation, cancers, and neurodegenerative diseases [1]. Antioxidants are compounds which terminate the action of free radicals, thereby protecting the body from oxidative damages. Many researchers have demonstrated that vitamins and polyphenols from plant sources including 
fruits, vegetables, grains, roots, tea, coffee, and wine showed good antioxidant activities, and could protect mitochondria from dysfunction and apoptosis [2,3]. Recently, it was found that edible and wild mushrooms possess vitamins and polyphenol compounds and exhibit strong antioxidant activities $[4,5]$. Therefore, it is necessary to find new potent antioxidants from other mushroom sources.

Diabetes mellitus (DM) is a chronic metabolic disease caused by the insufficient production of insulin from $\beta$-cells of the pancreas or reduced sensitivity of cells to insulin. DM is characterized by high levels of glucose in the blood and causes the highest rates of mortality worldwide. The increased blood glucose levels leads to acute and chronic complications such as blindness, kidney failure, and hepatic and cardiovascular diseases. Recently, it was also found that type 2 diabetes was associated with the dysfunction of mitochondria. The alterations in mitochondrial oxidative activity may cause an imbalance between oxidative capacity and nutrient load, and the induction of insulin resistance and insufficient secretion of insulin [6]. To date, there is no satisfactory therapy available to cure type 2 DM. Several drugs, $\alpha$-glucosidase inhibitors such as acarbose, voglibose, and miglitol, are now available to treat the patients who suffer from post-prandial hyperglycemia. These type of drugs inhibited degradation of carbohydrates in the digestive system, thereby reducing the glucose absorption by the cells and decreasing the blood glucose level. However, these drugs are associated with side effects such as yellow eyes or skin, and gastrointestinal disturbances including abdominal or stomach pains, diarrhea, passing of gas, thus searching for new natural anti-diabetic compounds is essential to overcome DM problems [7].

Alzheimer's disease (AD) is the most common cause of dementia. Dementia refers to symptoms including memory loss and difficulties with thinking or language. These symptoms occur when certain diseases, including AD, damage the brain. The enzyme acetylcholinesterase (AChE) hydrolyzes acetylcholine $(\mathrm{ACh})$, which is located at cholinergic brain synapses [8]. Recent evidence in scientific research has suggested that the dysfunction of mitochondria caused by oxidative stress were associated with AD and Parkinson's disease (PD) [9]. An acetylcholinesterase inhibitor (AChE), anti-cholinesterase, is a chemical that inhibits acetylcholinesterase from breaking down acetylcholine, thereby increasing the action of acetylcholine. AChE inhibitors can increase cholinergic transmission by preventing the hydrolysis of Ach, thereby making more ACh available at the cholinergic synapse. This makes inhibitors of AChE the most potent means of treating cognitive symptoms of AD. Donepezil, rivastigmine, galantamine, physostigmine, and tacrine are the commercially available AChE inhibitors for treating early stages of AD. However, for clinical use, these drugs are associated with side effects such as loss of appetite, dizziness, headache, vomiting, and diarrhea [10]. As such, the search for potent natural products that selectively inhibit AChE activity without side effects are necessary.

Inflammation is considered as a part of the complex biological response to remove injury or harmful stimuli such as ROS, pathogens, damaged cells, or irritation by thermal heat, ultraviolet light or ionizing radiations. Macrophages are large specialized cells that engulf and digest cellular debris, microbes, and cancer cells using a process called phagocytosis. In response to stimuli, including lipopolysaccharide, macrophages play a critical role in the inflammatory response by producing a variety of factors, such as nitric oxide (NO), prostaglandin mediators, and pro-inflammatory cytokines (TNF- $\alpha$, IL-1 $\beta$, IL-6) [11]. Chronic inflammation can cause various degenerative disorders, including arthritis, cancer, dementia, diabetes and multiple sclerosis, and is also involved in the pathogenesis of mitochondrial dysfunction [12,13]. Recently, non-steroidal anti-inflammatory drugs (NSAIDs) are among the most widely prescribed medications in clinical practice worldwide. However, many studies have shown that the long-term administration of NSAIDs has the potential for significant side effects on the gastrointestinal tract causing numerous harmful effects such as mucosal lesions, bleeding, and peptic ulcers [14]. Thus, it is necessary to develop safe and effective anti-inflammatory agents from natural sources including mushrooms.

Trametes pubescens, a mushroom belonging to the family Polyporaceae of the order Polyporales in the Basidiomycota, is used in folk medicine in Asian countries [15]. In spite of the importance of this mushroom as a natural fork medicine, there have only been a few studies on its physiologically relevant 
activities [16,17]. Thus, this study was initiated to assess the antioxidant, anti-diabetes, anti-dementia, and inflammation inhibitory effects of T. pubescens fruiting body extracts. The constituent of phenolic compounds of the mushroom was also analyzed.

\section{Results and Discussion}

\subsection{Antioxidant Activity Assay}

\subsubsection{DPPH Radical Scavenging Activity}

The 1,1-diphenyl-2-picryl-hydrazyl (DPPH) free radical scavenging activities of the ME and HWE from T. pubescens fruiting bodies increased as concentration of the extracts increased. The radical scavenging activity of methanol (ME) and hot water (HWE) extracts at $0.125-2.0 \mathrm{mg} / \mathrm{mL}$ ranged from $41.91 \%$ to $93.45 \%$, and from $9.62 \%$ to $92.38 \%$, respectively. However, at the range of same concentration of the positive control, butylated hydroxytoluene (BHT) showed excellent scavenging ability (96.19\%-96.97\%) (Figure 1). In general, the DPPH scavenging activity of the ME was higher than that of HWE in the range of $0.5-1.0 \mathrm{mg} / \mathrm{mL}(p<0.05)$. The highest scavenging activity $(93.45 \%)$ was observed in the ME $(2.0 \mathrm{mg} / \mathrm{mL})$, however, this value was significantly lower than that of BHT. These results suggest that $\mathrm{ME}$ of the mushroom contained good radical scavenging effects, whereas the HWE had moderate scavenging activity at the concentrations tested.

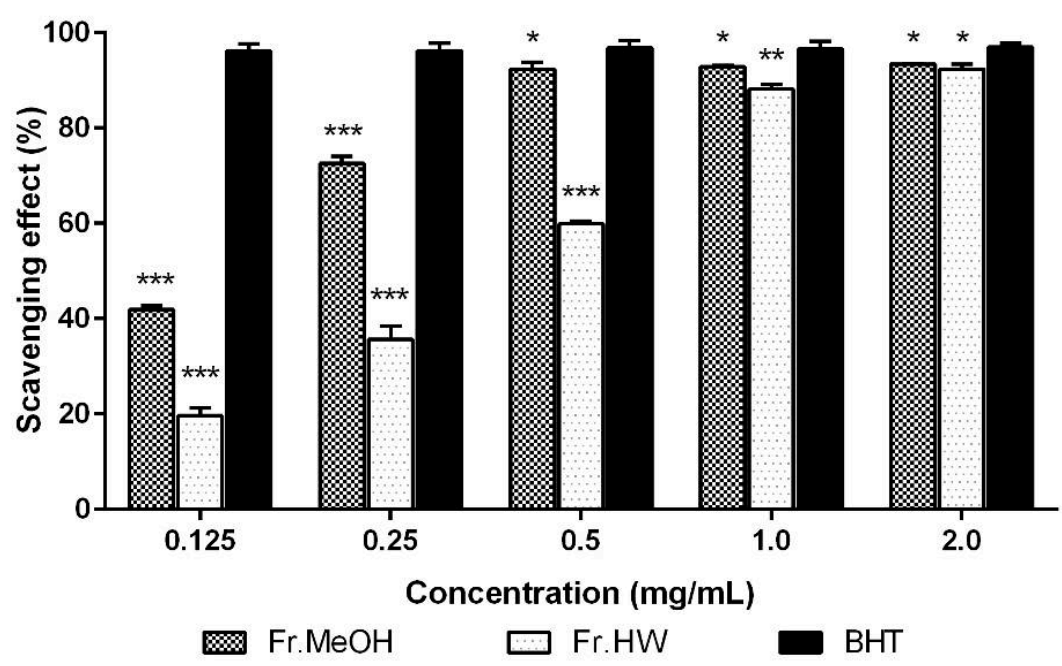

Figure 1. The 1,1-diphenyl-2-picryl-hydrazyl (DPPH) scavenging activities of methanol (ME) and hot water (HWE) extracts from fruiting bodies of Trametes pubescens on 1,1-diphenyl-2-picrylhydrazyl. Values are means \pm S.D $(n=3)$. Fr.MeOH, fractions extracted with $80 \%$ methanol; Fr.HW, fractions extracted with hot water; BHT, butylated hydroxytoluene. ${ }^{* *} p \leqslant 0.001 ;{ }^{* *} p \leqslant 0.01{ }^{*} p<0.05$ vs. BHT.

Sumathy et al. [18] reported that the DPPH scavenging activities of methanol and chloroform extracts of Pleurotus sajor-caju fruiting bodies were $85 \%-94 \%$ and $83 \%-89 \%$ at $1.0-5.0 \mathrm{mg} / \mathrm{mL}$, respectively. They further documented that the methanol and chloroform extracts of the carcophores of $P$. citrinopileatus had scavenging effects of $88 \%-96 \%$ and $86 \%-92 \%$, respectively, at the concentrations tested. Mau et al. [19] found that the radical scavenging abilities of methanol extracts from Grifola frondosa, Hericium erinaceus, Tricholoma giganteum, and Dictyophora indusiata ranged from $63.3 \%-92.1 \%$ at a concentration of $6.4 \mathrm{mg} / \mathrm{mL}$. Therefore, we conclude that the DPPH scavenging effects of the ME of T. pubescens fruiting body would be beneficial for human health. 


\subsubsection{Metal Chelating Effects}

The metal chelating activity of the ME and HWE from T. pubescens fruiting bodies was investigated. The chelating effects of ME and HWE at five different concentrations $(0.125-2.0 \mathrm{mg} / \mathrm{mL})$ ranged from $67.66 \%-91.62 \%$, and $59.23 \%-96.85 \%$, respectively (Figure 2), demonstrating an increase in chelation in accord with increasing extract concentrations. The highest chelating activity $(96.85 \%)$ was observed in the $2.0 \mathrm{mg} / \mathrm{mL}$ concentration of the HWE. At this concentration, slightly lower activity was detected in the ME $(91.62 \%)$, whereas the chelating ability of BHT (68.87\%) was significantly lower than those of both ME and HWE $(p<0.01)$.

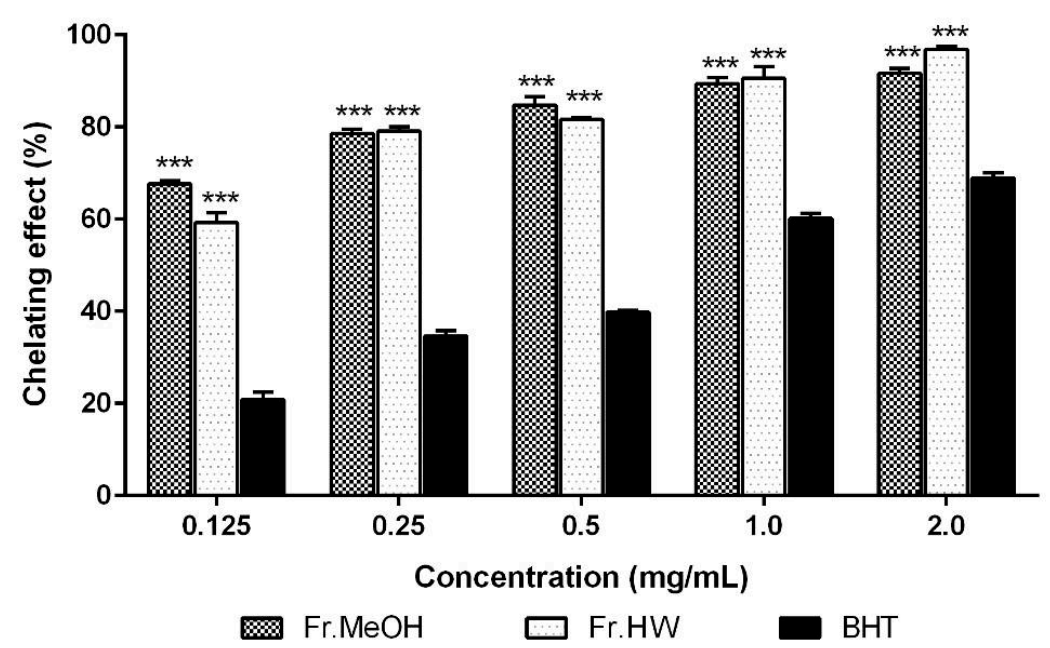

Figure 2. Chelating effect of methanol and hot water extract from fruiting bodies of Trametes pubescens at different concentrations. Values are means \pm S.D $(n=3)$. Fr.MeOH, fractions extracted with $80 \%$ methanol; Fr.HW, fractions extracted with hot water; BHT, butylated hydroxytoluene. ${ }^{* * *} p \leqslant 0.001$ vs. BHT.

Sarikurkcu et al. [20] reported that chelating activity on ferrous ion by the methanol extract of Amanita caesarea, Clitocybe geotropa, and Leucoagaricus pudicus were $74.1 \%, 37.2 \%$, and $97.6 \%$ at $2.0 \mathrm{mg} / \mathrm{mL}$, respectively. The chelating effects of methanol extracts from Auricularia fuscosuccinea, Auricularia polytricha, and Tremella fusiformis at $2.0 \mathrm{mg} / \mathrm{mL}$ were reported to be $91.28 \%, 88.04 \%$, and $86.92 \%$, respectively [21]. The ME and HWE determined herein exhibited significantly higher metal chelating activity than that of the standard reference, BHT, at the $0.125-2.0 \mathrm{mg} / \mathrm{mL}$ concentrations. Further, the ME and HWE of T. pubescens demonstrated higher chelating abilities than all mushrooms mentioned above except L. pudicus.

Ferrous ions are regarded as the strongest pro-oxidant among various metal ions. Chelating activity of ferrous ions can prohibit free radical generation and protect cells from oxidative damage by removing iron, which may be involved in free radical generation [22]. As ferrous ions are a potent pro-oxidant, the strong chelating activity found in T. pubescens fruiting bodies can be used as a natural antioxidant agent.

\subsubsection{Reducing Power}

The reducing powers of the ME and HWE from T. pubescens were analyzed and compared to BHT, the standard reference, at a range of $0.5-4.0 \mathrm{mg} / \mathrm{mL}$. At these concentrations, the ME (0.40-1.64) and HWE (0.383-2.16) showed significantly lower reducing power compared with BHT (2.83-2.92) $(p<0.001)$; however, the reducing power of the HWE at $6.0 \mathrm{mg} / \mathrm{mL}$ concentration was almost the same as BHT (Figure 3). These results show that the reducing power of the both extracts from T. pubescens increased steadily as the extract concentrations increased, whereas the reducing power of BHT increased slowly as the concentration increased. 


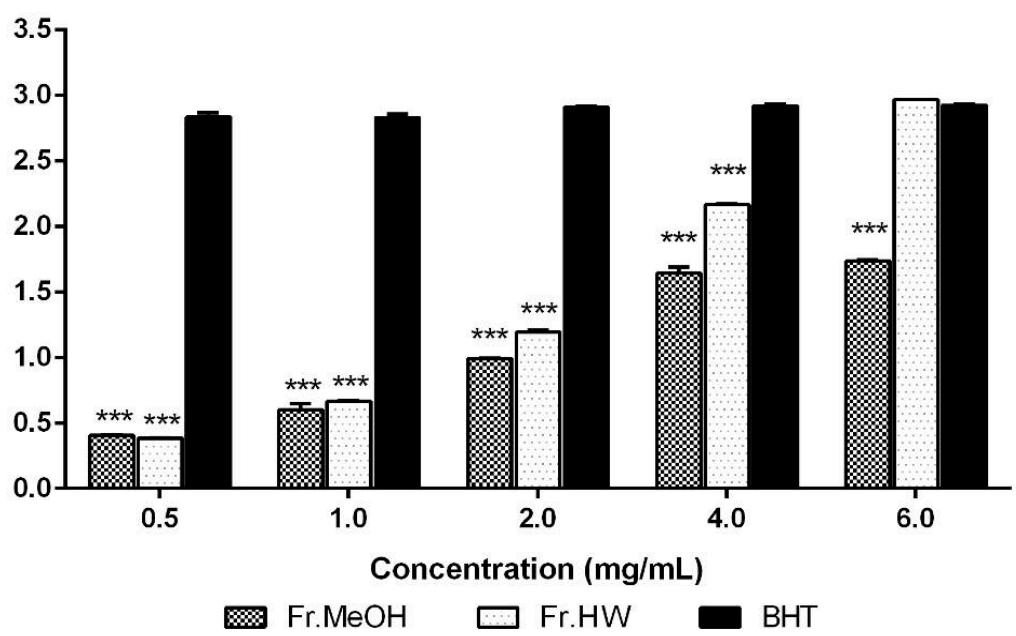

Figure 3. Reducing power of methanol and hot water extract from fruiting bodies of Trametes pubescens at different concentrations. Values are means \pm S.D $(n=3)$. Fr.MeOH, fractions extracted with $80 \%$ methanol; Fr.HW, fractions extracted with hot water; BHT, butylated hydroxytoluene; ${ }^{* * *} p \leqslant 0.001$ vs. BHT.

Lee et al. [23] documented that a ME and HWE from carcophores of Pleurotus citrinopileatus exhibited a reducing power of 1.03 and 1.10 at $5 \mathrm{mg} / \mathrm{mL}$, respectively, which is significantly lower than the ME and HWE tested herein, 1.64 and 2.16 at $4.0 \mathrm{mg} / \mathrm{mL}$, respectively. The reducing ability of the Hypsizygus marmoreus hot water extract was 0.99 at $5 \mathrm{mg} / \mathrm{mL}$ concentration [24], whereas those of A. fuscosuccinea, A. polytricha, and T. fuciformis were reported to be $2.19,1.21$, and 0.39 at $2.0 \mathrm{mg} / \mathrm{mL}$, respectively [21].

Our results indicate that $T$. pubescens has lower reducing power than the above-mentioned mushrooms, except $P$. citrinopileatus, H. marmoreus, and T. fuciformis. Generally, the reducing power of mushrooms are associated with their hydrogen-donating ability [24]. Therefore, the T. pubescens fruiting body possesses good amounts of reducing properties, which might react with free radicals and thereby exert antioxidant activity.

\subsection{HPLC Analysis of Phenolic Compounds}

High performance liquid chromatography (HPLC) was employed to determine the phenolic compound content of the extracts obtained from T. pubescens fruiting bodies. Eleven phenolic compounds were detected from the fruiting body of $T$ pubescens with the total concentration of $86.61 \mu \mathrm{g} / \mathrm{g}$ (Figure 4). The phenolic compounds detected included gallic acid $(18.8 \mu \mathrm{g} / \mathrm{g})$, protocatechuic acid $(2.92 \mu \mathrm{g} / \mathrm{g}),(-)$-epigallocatechin gallate $(14.8 \mu \mathrm{g} / \mathrm{g})$, caffeic acid $(4.81 \mu \mathrm{g} / \mathrm{g})$, rutin hydrate $(7.11 \mu \mathrm{g} / \mathrm{g}), p$-coumaric acid $(3.58 \mu \mathrm{g} / \mathrm{g})$, naringin $(11.09 \mu \mathrm{g} / \mathrm{g})$, resveratrol $(2.34 \mu \mathrm{g} / \mathrm{g})$, kaempferol $(6.74 \mu \mathrm{g} / \mathrm{g})$, and biochanin-A $(7.19 \mu \mathrm{g} / \mathrm{g})$ (Figure 4B). The lowest and highest phenolic compound concentrations were protocatechuic acid and gallic acid, respectively. These results were comparable with those of previous findings in edible and medicinal mushrooms, where mushroom species had three to five different types of phenolic compounds, with gallic acid and protocatechuic acid being the most common [25].

Phenolic compounds are classified as simple phenols, phenolic acids, and polyphenols. Flavonoids are a group of polyphenolic compounds with well-known beneficial properties to health, such as free radical scavenging, hydrolytic inhibition, and anti-inflammatory activity [26,27]. Several papers have shown a positive correlation between phenolic compound concentrations and antioxidant activities. In general, phenolic compounds possess one or more aromatic rings with large numbers of hydroxyl groups, and thereby display a diverse structural diversities, exhibit radical scavenging, metal ion chelating, and reducing power, which resulted in good antioxidant effects $[28,29]$. 

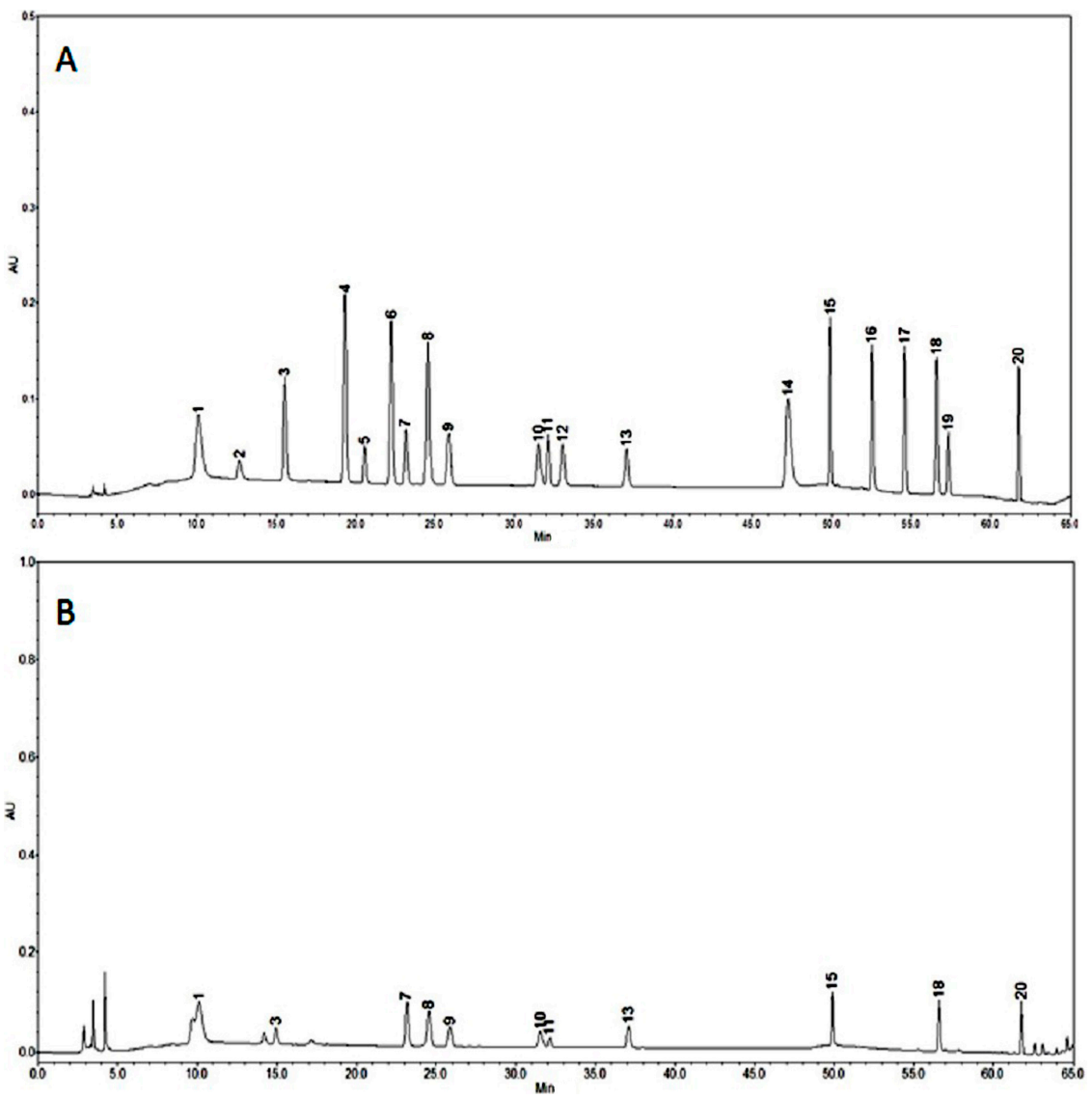

Figure 4. High performance liquid chromatography (HPLC) analysis of phenolic compounds. (A) standard compounds; (B) Trametes pubescens; 1, gallic acid; 2, homogentisic acid; 3, protocatechuic acid; 4, (+)-catechin; 5, chlorogenic acid; 6, (-)-epicatechin; 7, (-)-epigallocatechin gallate; 8, caffeic acid; 9 , vanillin; 10, rutin hydrate; 11, p-coumaric acid; 12 , ferullic acid; 13, naringin; 14, myricetin; 15 , resveratrol; 16, quercetin; 17 , naringenin; 18 , kaempferol; 19 , formonoentin; 20, biochanin-A.

\subsection{In Vitro Anti-Diabetic Assay}

\subsection{1. $\alpha$-Amylase Inhibitory Activity}

The $\alpha$-amylase inhibitory effects of the ME and HWE from T. pubescens fruiting bodies increased steadily with increasing concentration of T. pubescens. The inhibitory effects of the ME and HWE ranged from $27.75 \%$ to $69.46 \%$, and from $10.05 \%$ to $53.82 \%$ at $0.125-2.0 \mathrm{mg} / \mathrm{mL}$, respectively. However, Acarbose, the stand reference, showed excellent $\alpha$-amylase inhibitory ability, ranging from $40.61 \%$ to $89.91 \%$ at $0.125-2.0 \mathrm{mg} / \mathrm{mL}$ (Figure 5). In general, the $\alpha$-amylase inhibitory activity of the $\mathrm{ME}$ was significantly higher than that of HWE in the concentration range of $0.5-2.0 \mathrm{mg} / \mathrm{mL}(p<0.05)$. The highest inhibition activity $(69.46 \%)$ was observed in the $\mathrm{ME}$ at $2.0 \mathrm{mg} / \mathrm{mL}$, however, this inhibitory activity was significantly lower than that of Acarbose, the reference drug. The results showed that the ME of mushroom had good inhibitory activity, whereas the HWE exhibited moderate activity at the concentrations examined. Santhoshkumar and Nagarajan [30] reported that $\alpha$-amylase inhibitory effects of methanol extract of Ganoderma lucidum fruiting bodies were $21.92 \%$ to $94.46 \%$ at $0.2-1.0 \mathrm{mg} / \mathrm{mL}$, respectively, whereas Pandimeena [31] documented that $\alpha$-amylase inhibitory activity of methanolic extract of Pleurotus florida fruiting bodies were $13.78 \%-26.5 \%$ at the $0.25-1.0 \mathrm{mg} / \mathrm{mL}$, respectively [31]. Our results demonstrated that ME of T. pubescens fruiting bodies possess relatively effective $\alpha$-amylase inhibitory activities at $0.125-0.5 \mathrm{mg} / \mathrm{mL}$ concentrations compared with the mushrooms described above. 


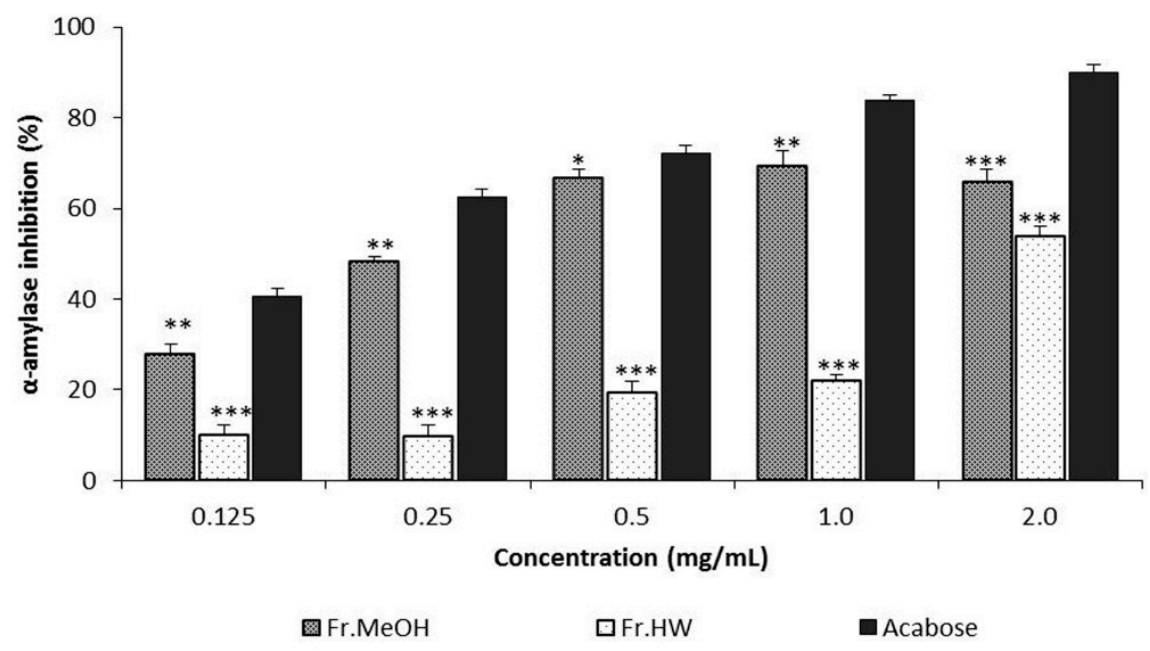

Figure 5. The $\alpha$-amylase inhibitory activity of methanol and hot water extract of Trametes pubescens fruiting bodies. Values are means \pm S.D $(n=3)$. Fr.MeOH, fractions extracted with $80 \%$ methanol; Fr.HW, fractions extracted with hot water; ${ }^{* * *} p \leqslant 0.001,{ }^{* *} p \leqslant 0.01,{ }^{*} p \leqslant 0.05$ vs. Acarbose.

\subsection{2. $\alpha$-Glucosidase Inhibitory Activity}

The control of the early stage of DM is crucial for preventing chronic DM development. Several synthetic drugs are now available to treat DM, including $\alpha$-glucosidase inhibitors (AGIs). AGIs work in the gastrointestinal tract by inhibiting digestion of starch, thereby increase the glycemic control and postprandial hyperglycemia modulation [32]. In this experiment, $\alpha$-glucosidase inhibitory effects of fruiting body extracts of $T$. pubescens increased gradually with the increasing extract concentration. The inhibitory activities of ME and HWE ranged from $36.64 \%$ to $51.24 \%$, and from $36.88 \%$ to $53.05 \%$ at $0.125-2.0 \mathrm{mg} / \mathrm{mL}$, respectively. In contrast, Acarbose, the reference drug, exhibited the highest inhibitory activity at $0.125-2.0 \mathrm{mg} / \mathrm{mL}$, ranging from $37.27 \%$ to $81.81 \%$ (Figure 6). The $\alpha$-glucosidase inhibitory effects of both ME and HWE were similar in the range of $0.5-2.0 \mathrm{mg} / \mathrm{mL}$ concentration $(p<0.05)$. The highest inhibitory activity $(53.05 \%)$ was detected in the HWE $(2.0 \mathrm{mg} / \mathrm{mL})$, however, this inhibitory activity was significantly lower than that of Acarbose. These results indicate that ME and HWE of the mushroom possessed moderate inhibitory activities against $\alpha$-glucosidase. Santhoshkumar and Nagarajan [30] found that the inhibition of $\alpha$-glucosidase by the methanol extract of Ganoderma lucidum fruiting bodies were $32.74 \%-86.53 \%$ at $0.2-1.0 \mathrm{mg} / \mathrm{mL}$, which exhibited higher $\alpha$-glucosidase inhibitory activity compared to our experimental results. Yin et al. [33] reported that constituents exhibiting $\alpha$-glucosidase inhibitory activity from medicinal plants consist of various components, including terpenes, alkaloids, quinines, flavonoids, phenols, phenylpropanoids, sterides, and other types of compounds. Su et al. [34] found that major active components exhibiting $\alpha$-glucosidase inhibition from fruiting bodies, including Grifola frondosa, Hericium erinaceum, Agaricus blazei, Ganoderma lucidum, Coriolus versicolor, and Phellinus linteus, were composed of oleic and linoleic acids. Therefore, it is suggested that the moderately high concentration of phenolic and other compounds present in the mushroom extracts may contribute to moderately higher $\alpha$-glucosidase inhibitory activity. 


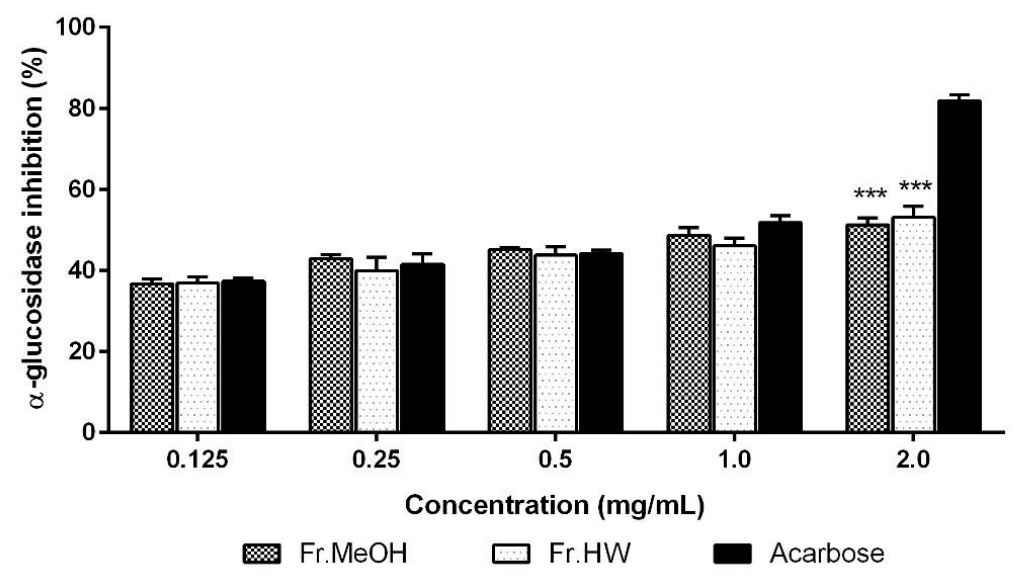

Figure 6. The $\alpha$-glucosidase inhibitory activity of methanol and hot water extract from fruiting bodies of Trametes pubescens. Values are means \pm S.D $(n=3)$. Fr.MeOH, fractions extracted with $80 \%$ methanol; Fr.HW, fractions extracted with hot water; ${ }^{* * *} p \leqslant 0.001$ vs. Acarbose.

\subsection{Anti-Dementia Assay}

\subsubsection{Anti-Acetylcholinesterase Activity}

AChE, known as acetylhydrolase, catalyzes the hydrolysis of acetylcholine, one of the neurotransmitters found in the cholinergic brain synapses, where AChE serves to terminate synaptic transmission. The activities of $\mathrm{AChE}$ can lead to neurological disorders such as $\mathrm{AD}$, senile dementia, and ataxia [35]. The anti-AChE effects from fruiting body extracts of T. pubescens were investigated herein. At concentrations ranging from 0.063 to $1.0 \mathrm{mg} / \mathrm{mL}$, the inhibitory effects of the ME and HWE from the T. pubescens fruiting body ranged from $51.70 \%$ to $90.94 \%$, and from $47.21 \%$ to $83.15 \%$, respectively (Figure 7), and demonstrated concentration-dependent inhibition. The AChE inhibitory effect obtained from the ME was higher than that of the HWE at $0.063-1.0 \mathrm{mg} / \mathrm{mL}$, whereas the inhibitory effects of galanthamine $(97.80 \%)$, the standard reference, was significantly higher $(p<0.01)$ than both extracts.

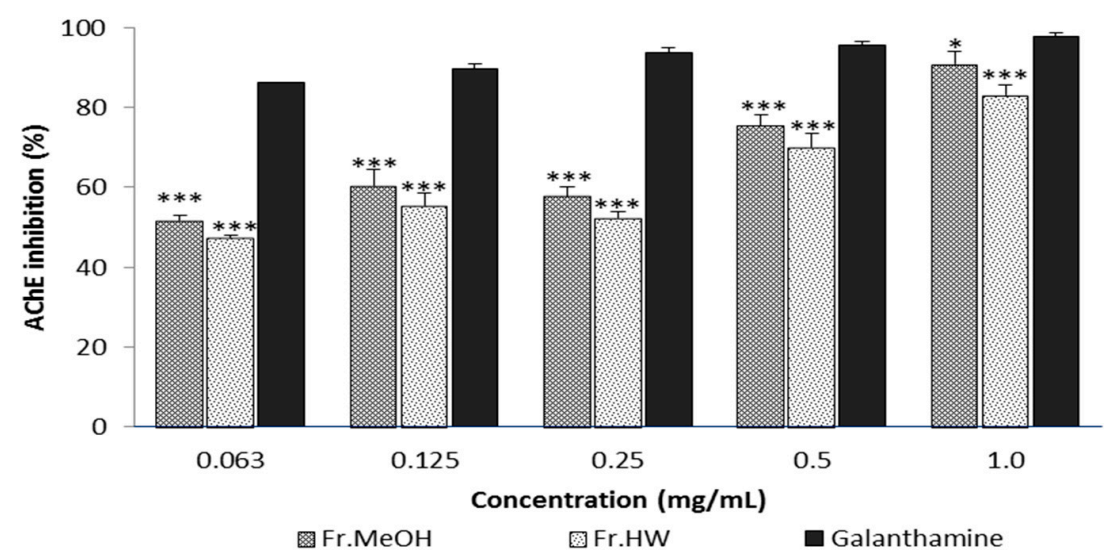

Figure 7. Acetylcholinesterase inhibitory activity of methanol and hot water extract of T. pubescens fruiting bodies. Values are means \pm S.D $(n=4)$. Fr.MeOH, fractions extracted with $80 \%$ methanol; Fr.HW, fractions extracted with hot water. ${ }^{* * *} p \leqslant 0.001 ;{ }^{*} p<0.05$ vs. galanthamine.

Previous reports documented that phenolic acids and flavonoid derivatives such as gallic acid, chlorogenic acid, quercetin, caffeic acid, ferulic acid, ellagic acid, catechin, rutin, and luteoin-7-rutinoside, are strong inhibitors of the AChE enzyme [36]. Our experimental results (Figure 4B) also indicate that the fruiting body of T. pubescens contains 11 different phenolic compounds including gallic acid $(18.8 \mu \mathrm{g} / \mathrm{g})$, 
caffeic acid $(4.81 \mu \mathrm{g} / \mathrm{g})$, and rutin hydrate $(7.11 \mu \mathrm{g} / \mathrm{g})$, which have strong AChE inhibitory potential. These results support the previous findings concerning phenolic acids and flavonoids mentioned above. Therefore, we conclude that the high AChE inhibitory activity found in the ME and HWE may be due to the polyphenolic compounds in the fruiting bodies.

\subsubsection{Anti-Butyrylcholinesterase Activity}

The butyrylcholinesterase (BChE) inhibitory activities of ME and HWE from T. pubescens fruiting bodies were analyzed and compared with galanthamine, the standard reference. The BChE inhibitory effects of the ME (49.49\%-75.73\%) and HWE (47.93\%-63.58\%) were significantly lower than that of galanthamine $(50.56 \%-81.12 \%)$ at $0.063-1.0 \mathrm{mg} / \mathrm{mL}(p<0.001)$. The AChE inhibitory activity of both extracts increased with as their respective concentrations increased (Figure 8).

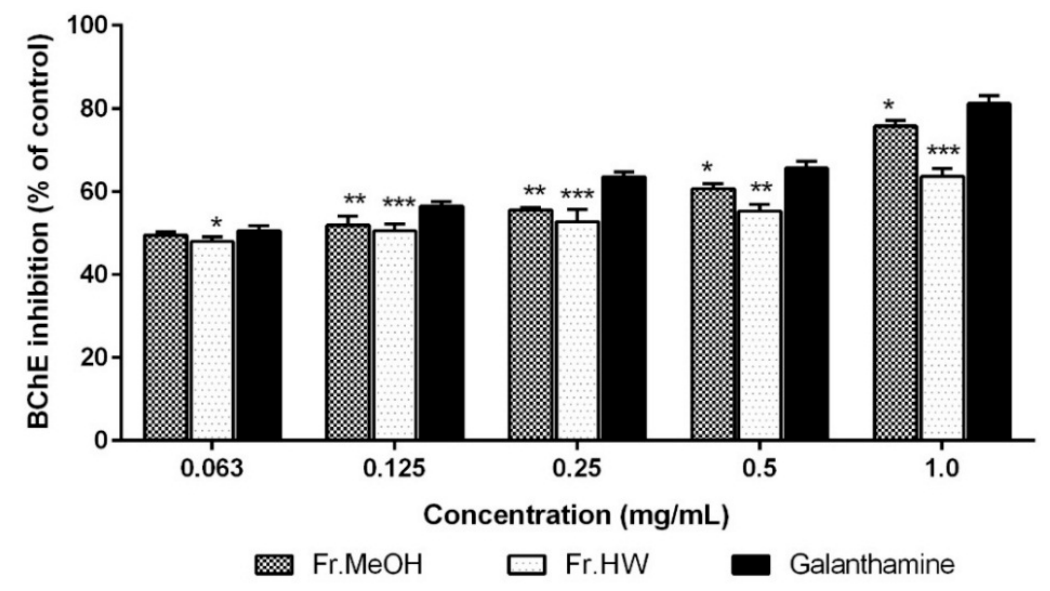

Figure 8. Butylrylcholinesterase (BChE) inhibitory activity of methanol and hot water extract of T. pubescens fruiting bodies. Values are means \pm S.D $(n=4)$. Fr.MeOH, fractions extracted with $80 \%$ methanol; Fr.HW, fractions extracted with hot water. ${ }^{* * *} p \leqslant 0.001 ;{ }^{* *} p \leqslant 0.01 ;{ }^{*} p<0.05$ vs. galanthamine.

Orhan et al. [37] screened four phenolic acids and 10 flavonoid derivatives for BChE inhibitory activities and found chlorogenic acid, gallic acid, quercetin, genistein, leteolin-7-O-galactoside, naringin, silibinin, and silymarin to have inhibitory activities. In our experiment, two of those phenolic compounds, gallic acid and naringin, were found in the fruiting bodies of T. pubescens. These results could explain the high and moderate inhibitory activities of the fruiting body extracts of T. pubescens toward the BChE enzyme.

\subsubsection{Glutamate-Induced Cytotoxicity}

Glutamate is one of neurotransmitter in the central nervous system of mammals. However, excessively released glutamate in the system can lead to neuronal damage and cell death in a process known as excitotoxicity. A recent study suggested that the oxidative stress could cause mitochondrial dysfunction, and this event was mediated by glutamate-induced excitotoxicity and associated with neurodegenerative disorders [38].

A pheochromocytoma cell line (PC-12) derived from rat adrenal medulla, was used to evaluate the glutamate-induced cytotoxicity. The cell viability of PC-12 cells supplemented with $10 \mathrm{mM}$ glutamate was $56.65 \%$ compared with the control, whereas the viabilities after 5, 10, 20, 40, and $100 \mu \mathrm{g} / \mathrm{mL}$ of ME supplementation were $43.63 \%, 53.32 \%, 78.73 \%, 76 \%, 35 \%$, and $41.27 \%$, respectively. In contrast, the viabilities of glutamate-treated PC-12 cells were $34.40 \%, 40.15 \%, 46.85 \%, 45.40 \%$, and 31.47\%, respectively, after treatment with the same concentrations of the HWE (Figure 9). These results suggest that the cytotoxicity of PC-12 cells induced by glutamate treatment was attenuated by the addition 
of the ME at the concentrations of 20 and $40 \mu \mathrm{g} / \mathrm{mL}$, whereas the supplementation of 5, 10, and $100 \mu \mathrm{g} / \mathrm{mL}$ could not mitigate the cytotoxicity. However, the hot water extracts could not improve the cell viabilities compared with the glutamate-treated group at any concentration. The ME of T. pubescens only significantly alleviated the glutamate-induced cytotoxicity on PC-12 cells at 20 and $40 \mu \mathrm{g} / \mathrm{mL}$.

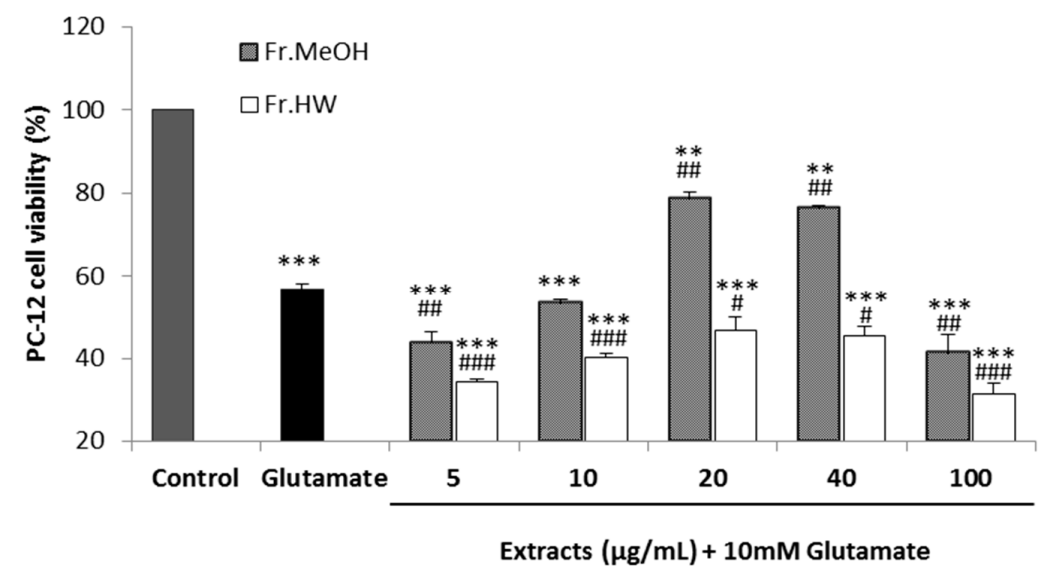

Figure 9. Glutamate-induced cytotoxicity activity of methanol and hot water extract from fruiting body of Tramates pubescens against pheochromocytoma cell line (PC-12). Values are means \pm S.D $(n=4)$. *** $p \leqslant 0.001 ;{ }^{* *} p \leqslant 0.01$ vs. control group; ${ }^{\# \# \#} p \leqslant 0.001 ;{ }^{\# \#} p \leqslant 0.01 ;{ }^{\#} p \leqslant 0.05$ vs. glutamate.

Lee et al. [39] reported that PC-12 cell treatment with (-)-epigallocatechin gallate (EGCG), a polyphenol from green tea, reduced the glutamate-induced $\mathrm{Ca}^{2+}$ influx increase, while also increasing the viability of PC-12 cells against glutamate-induced cytotoxicity. Tan et al. [40] also found that various concentrations of biochanin-A from Trifolium pratense attenuated the glutamate-induced PC-12 cell cytotoxicity. In the present study, the ME extract significantly increased viability of PC-12 cells from glutamate-induced cytotoxicity, indicating that various phenolic compounds present in the mushroom fruiting body exerted free radical scavenging activities on the ROS generated by glutamate supplementation, and thereby protected the cells from death.

\subsection{Inflammation Inhibitory Assay}

\subsubsection{Production of NO}

Macrophages play pivotal roles in inflammatory process by producing several pro-inflammatory molecules, including NO. Evidence has indicated that excessively produced NO has been associated with various inflammation-related ailments such as arteriosclerosis, hypertension, and septic shock [41]. To evaluate the inhibitory effect of the mushroom extracts on the production of NO, lipopolysaccharide (LPS)-induced macrophage-like cell-lines (RAW 264.7) were used. The concentration of NO after treating LPS on RAW 264.7 macrophages for $24 \mathrm{~h}$ increased $~ 6.73$-fold (6.47-43.55 $\mu \mathrm{M})$, while the NO concentration from the varying T. pubescens extract concentration treatments decreased significantly in a concentration-dose dependent manner from 0.5 to $2 \mathrm{mg} / \mathrm{mL}$ (Figure 10).

RAW 264.7 macrophages treated only with $2 \mathrm{mg} / \mathrm{mL}$ of ME produced $8.21 \mu \mathrm{M}$ of $\mathrm{NO}$, which is comparable with the $6.47 \mu \mathrm{M}$ of LPS non-treating group. However, LPS-treated RAW 264.7 macrophages supplemented with $2 \mathrm{mg} / \mathrm{mL}$ ME produced $8.67 \mu \mathrm{M}$ of NO, indicating a 1.34-fold higher concentration than the control (Figure 10A). The RAW 264.7 macrophages treated with $2 \mathrm{mg} / \mathrm{mL}$ of HWE also showed a significant decrease in the production of NO by $69.58 \%$ compared with the group treated only LPS (Figure 10B). These results show that the inhibitory activity of the ME on the LPS-induced NO production in RAW 264.7 macrophages was significantly higher than that of the HWE. The higher inhibitory effect of NO production in ME over HWE may be due to some ingredient of the fruiting body exhibiting anti-inflammatory effects that were inactivated by hot 
water heating. The cytotoxic effect on RAW 264.7 macrophages was not observed from both of the extracts by the MTT test (data not shown). These experimental results suggest that the inhibition of NO production by treatment of the ME and HWE on RAW 264.7 macrophages was due to reduced expression of inducible nitric oxide (iNOS) protein. Song et al. [42] found that NO production in LPS-induced RAW 264.7 macrophages was suppressed by ethanolic extract of Ganoderma lucidum fruiting bodies in a concentration-dependent manner. Furthermore, Moro et al. [11] reported that the methanol extracts with rich phenolic compounds from fruiting bodies of wild edible mushrooms such as Agaricus bisporus, Cantherellus cibarius, Lactarius deliciosus, and Craterellus cornucopioides, suppressed NO production in LPS-induced RAW 264.7 macrophages. Park et al. [43] documented that methanol extract of Inonotus obliquus attenuated NO production significantly on LPS-stimulated macrophages by inhibiting proteins and mRNA expressions of inducible nitric oxide (iNOS) and cyclooxygenase-2 (COX-2). It was reported that the strong anti-inflammatory components detected in mushrooms such as P. ostreatus, Macrolepiota procera, Boletus impolitus, and Agaricus bisporus were phenolic compounds including cinnamic acid, $p$-coumaric acid, and $p$-hydroxybenzoic acids and their derivatives [44]. Therefore, we conclude that the higher inhibitory effect on LPS-induced NO production from RAW 264.7 cells by T. pubescens fruiting body extracts was due to phenols and other compounds present in the mushroom extracts, and that the inhibitory effects herein were similar to those of mushrooms mentioned above.
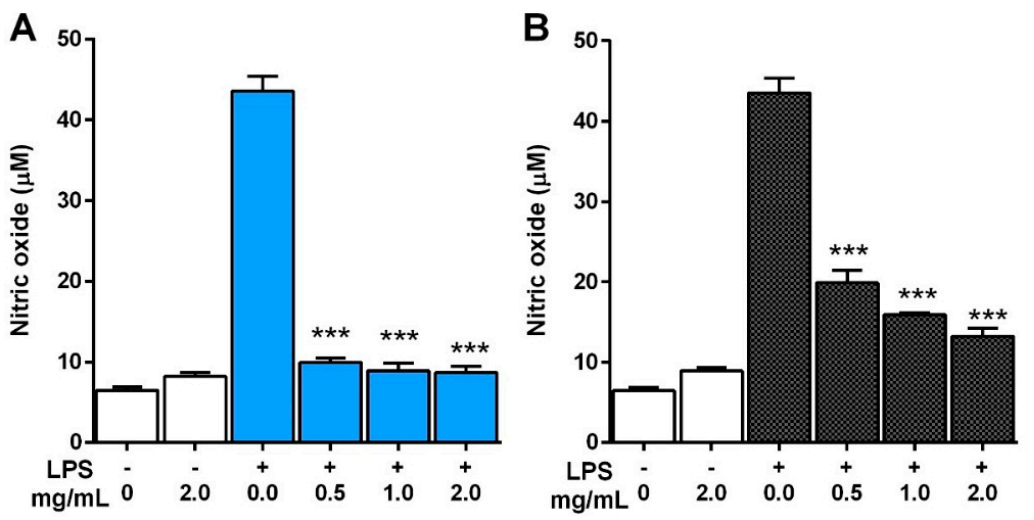

Figure 10. Inhibitory effect of Trametes pubescens fruiting bodies on lipopolysaccharide (LPS)-induced nitric oxide production in murine macrophage-like cell-lines (RAW 264.7): (A) methanol extract; (B) hot water extract. Nitric oxide in the culture medium was determined by the Griess reaction assay. Values are means \pm S.D $(n=3) .{ }^{* *} p<0.001$ vs. LPS-treated group.

\subsubsection{Western Blot Analysis}

LPS-induced RAW264.7 macrophages showed a dose-dependent reduction in NO production after treatment with the ME and HWE of T. pubescens. This line of experiments was performed under the assumption that the suppressed NO production was due to suppression of iNOS expression. To investigate the expression of iNOS protein by the mushroom extracts, a Western blot analysis was conducted. Since the ME showed the highest inhibitory effect on the NO production in this experiment, LPS-stimulated RAW 264.7 macrophages treated with the ME was used for the Western blot analysis.

The amount of iNOS protein decreased by treating ME in a dose-dependent manner, while the expression of $\beta$-actin protein was not changed, indicating that only iNOS expression was suppressed by the ME (Figure 11). Chen et al. [45] reported that the glycoprotein isolated from fruiting bodies of Pleurotus citrinopileatus inhibited the NO production and expression of iNOS in LPS-induced RAW 264.7 cell lines in a dose-dependent manner. Wu et al. [46] reported that the ethanol extract from Armillariella mellea fruiting bodies also suppressed NO production and expression of the iNOS protein in LPS-stimulated RAW 264.7 macrophages. These results suggest that reduced NO production and expression of the iNOS protein in the RAW 264.7 cells may be due to the mushroom extract treatment. 


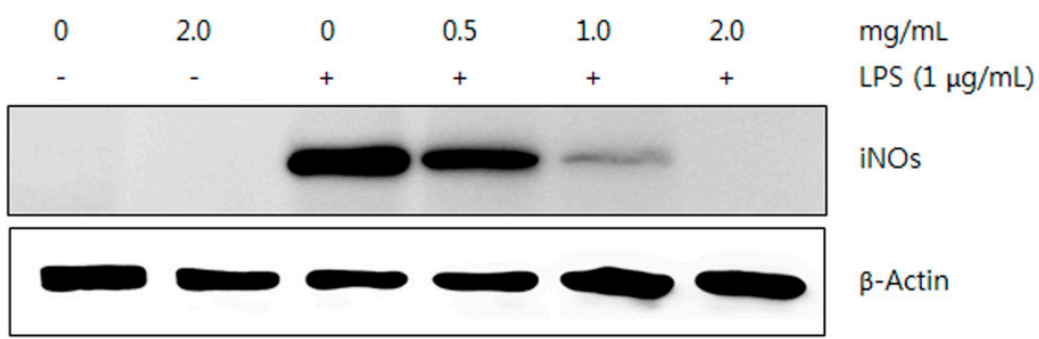

Figure 11. Inhibitory effect of methanol extract from Trametes pubescens fruiting bodies on LPS-induced expression of nitric oxide synthase (iNOS) in RAW 264.7 cells. $\beta$-Actin was used as an internal control.

\subsubsection{Carrageenan-Induced Paw Edema}

The process of carrageenan-induced edema can be classified by two phases. The initial phase is characterized by releasing histamine, serotonin, and kinin, while the late phase is involved in the release of bradykinin and prostaglandin. The release of histamine in the initial stage leads to the outward movement of proteins and fluid into the extracellular spaces, while the prostaglandin produced during the late phase is responsible for the edema formation and most of drugs for anti-inflammatory treatment are more effective in the late stage of edema development [47].

The ME of T. pubescens exhibited concentration-dependent anti-inflammatory activity and significantly decreased the edema volume in the hind paw of rats $(p<0.001)$. As shown in Figure $12,6 \mathrm{~h}$ after subcutaneous injection, indomethacin, the reference drug, reduced the rat paw edema significantly $(55.09 \%)$, whereas the administration of $\operatorname{ME~}(5,15$, and $50 \mathrm{mg} / \mathrm{kg})$ caused a reduction of paw edema by $26.74 \%, 27.67 \%$ and $46.05 \%$, respectively. The $5-50 \mathrm{mg} / \mathrm{kg}$ doses of ME showed a highly significant reduction of the paw edema at 2, 4, and $6 \mathrm{~h}$ after the initiation of edema compared with the control $(p<0.001)$. Although the inhibitory effect of indomethacin on the carrageenan-induced edema of rats was significantly higher than that of the ME at a dose of $50 \mathrm{mg} / \mathrm{kg}(p<0.01)$, the effects of ME were comparable. It was also found that methanol extract from I. obliquus significantly reduced volume of carrageenan-induced paw edema of rats compared with the control, however the inhibitory effect of the methanol extract was significantly lower than that of ibuprofen, the positive control [43].

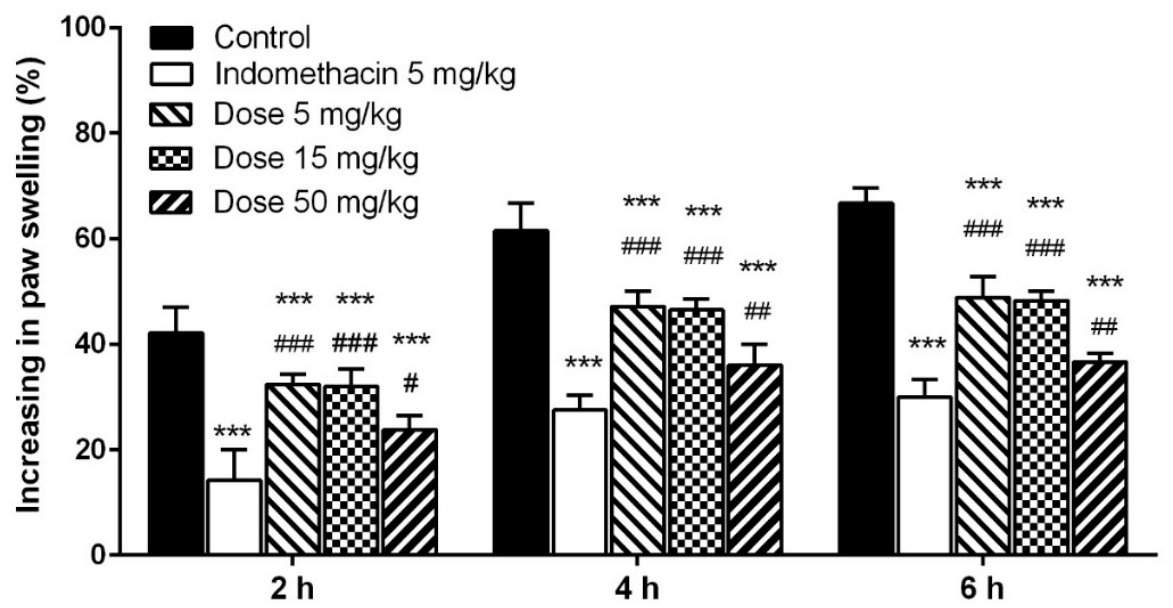

Figure 12. Effect of methanol extract from Trametes pubescens fruiting bodies on carrageenan-induced hind paw edema. Values are means \pm S.D $(n=5) .{ }^{\# \#} p \leqslant 0.001 ;{ }^{\# \#} p \leqslant 0.01 ;{ }^{\#} p<0.05$ vs. indomethacin group. ${ }^{* * *} p \leqslant 0.001$ vs. control group.

Therefore, in vitro antioxidant and in vivo inflammation inhibitory effects found in T. pubescens fruiting bodies may be useful for treating inflammation related disorders. 


\section{Materials and Methods}

\subsection{Chemicals and Reagents}

All phenolic standards, methanol, butylated hydroxytoluene (BHT), 1,1-diphenyl-2-picryl-hydrazyl (DPPH), ferric chloride, ferrous chloride, ferrozine, potassium ferricyanide, trichloroacetic acid, Folin-Ciocalteu reagent, 3,4-dihydroxy-L-phenylalanine, dimethyl sulfoxide, tris-HCL, tris base, glacial acetic acid, trichloroacetic acid, acarbose, $p$-nitrophenyl- $\alpha$-D-glucopyranoside, 5,5'-dithiobis-(2-nitrobenzoic acid) (DTNB), galanthamine, lipopolysaccharides (LPS), and carrageenan were purchased from Sigma-Aldrich (St. Louis, MO, USA). The iNOS antibody was purchased from Santa Cruz Biotechnology Co, and an ECL kit was purchased from Amersham Co (GE Healthcare Life Sciences, Buckinghamshire, UK).All chemicals and solvents used for the experiment and high performance liquid chromatography (HPLC) were of analytical grade.

\subsection{Experimental Animals}

Inbred male rats (Sprague Dawley, five weeks old, 140-160 g) were obtained from Animal Inc., Seoul, Korea, and used for this experiment. Animals were housed under temperature at $23 \pm 2{ }^{\circ} \mathrm{C}$, relative humidity $(50 \%-60 \%)$, and a 12/12 h dark and light cycle. A standard diet and water were supplied to the animals ad libitum. Animals were kept in an animal house one week for acclimation before experiment. Experimental procedures have been performed in accordance with the animal care guidelines of Animal Ethics Committee at the Incheon National University and the protocol was evaluated and approved by the committee (Ethics no. 117-2.28.2014).

\subsection{Mushroom Extract}

T. pubescens fruiting bodies were collected from Incheon City Grand Park and identified by Dr. Kyung-Rim Lee (mycologist). The voucher specimen (IUM 4605) was deposited in the "Culture Collection of Mushrooms", Incheon National University. The T. pubescens fruiting bodies were fully air dried at $45^{\circ} \mathrm{C}$ and ground into a fine powder.

To obtain the methanol extract (ME), 10 grams of the powder was extracted with $200 \mathrm{~mL}$ of $80 \%$ methanol at orbital shaker $(150 \mathrm{rpm})$ for $24 \mathrm{~h}$ at $25^{\circ} \mathrm{C}$. Then, the mixture was filtered through filter paper. To obtain the hot water extract (HWE), $10 \mathrm{~g}$ of the powder was boiled for $3 \mathrm{~h}$ in $200 \mathrm{~mL}$ of distilled water, cooled to $25^{\circ} \mathrm{C}$ and filtered with filter paper. Then, the remaining residue was extracted with $200 \mathrm{~mL}$ of methanol or distilled water twice as described above, respectively. The ME and HWE were evaporated to dryness at $40{ }^{\circ} \mathrm{C}$ under reduced pressure in a rotary evaporator and remaining solvent were removed with a freeze-drier.

\subsection{Antioxidant Activity}

\subsubsection{DPPH Radical Scavenging}

DPPH free radical scavenging activity was measured according to the methods described by Galvez et al. [48] with minor modifications. One $\mathrm{mL}$ of $0.1 \mathrm{mM}$ DPPH radical solution in methanol was mixed with $1 \mathrm{~mL}$ aliquots of varying mushroom extract concentrations $(0.125,0.25,0.5,1.0$ and $2.0 \mathrm{mg} / \mathrm{mL}$ ). The reaction was carried out by shaking vigorously and then allowing it to stand for $30 \mathrm{~min}$ in the dark before measuring the absorbance at $517 \mathrm{~nm}$ by a UV-Vis spectrophotometer. The percent inhibition of DPPH radicals was calculated as following formula:

$$
\text { Inhibition } \%=\left[\left(A_{c}-A_{s} / A_{c}\right)\right] \times 100
$$

where $A_{c}$ is the absorbance of the control and $A_{s}$ is the absorbance of the test compound. BHT was used as a standard reference. 


\subsubsection{Chelating Effects on Ferrous Ions}

The chelating ability of ferrous ions was investigated according to the method described by Sowndhararajan and Kang [49] with slight modification. Two mL of methanol aliquots of varying concentrations of the extracts $(0.063,0.125,0.25,0.5$, and $1.0 \mathrm{mg} / \mathrm{mL})$ were mixed with $0.05 \mathrm{~mL}$ of $2 \mathrm{mM} \mathrm{FeCl}_{2}$ solution. Then, $2.95 \mathrm{~mL}$ of methanol was added to adjust the total volume of $5 \mathrm{~mL}$ and allowed to stand for $10 \mathrm{~min}$ at $25^{\circ} \mathrm{C}$. Half a $\mathrm{mL}$ of varying extract concentrations were mixed with $0.5 \mathrm{~mL}$ of $\mathrm{FeSO}_{4}(0.12 \mathrm{mM})$ and $0.5 \mathrm{~mL}$ of ferrozine $(0.6 \mathrm{mM})$. The reaction was carried out by shaking the mixture vigorously. After $10 \mathrm{~min}$ of incubation at $25^{\circ} \mathrm{C}$, the absorbance was measured by a UV-Vis spectrophotometer at $562 \mathrm{~nm}$. The percent of the sample's ability to chelate ferrous ions was calculated by following formula:

$$
\text { Ferrous ion chelating ability }(\%)=\left[\left(\mathrm{A}_{\mathrm{c}}-\mathrm{A}_{\mathrm{S}}\right) / \mathrm{A}_{\mathrm{c}}\right] \times 100
$$

where $A_{c}$ is the absorbance of the control and $A_{s}$ is the absorbance of the test compound. BHT was used as a standard reference

\subsubsection{Reducing Power Assay}

The reducing power was investigated by the method of Glucin et al. [50]. Varying concentrations $(0.5,1.0,2.0,4.0,6.0 \mathrm{mg} / \mathrm{mL})$ of $\mathrm{ME}$ and HWE in methanol were mixed with $2.5 \mathrm{~mL}$ of $200 \mathrm{mM}$, sodium phosphate buffer ( $\mathrm{pH}$ 6.6) and $2.5 \mathrm{~mL}$ of potassium ferricyanide (1\%). The mixture was kept at $50{ }^{\circ} \mathrm{C}$ for $20 \mathrm{~min}$. Then, the reaction mixture was acidified with $2.5 \mathrm{~mL}$ of trichloroacetic acid (10\%), centrifuged at $650 \mathrm{rpm}$ for $10 \mathrm{~min}$ and $5 \mathrm{~mL}$ of supernatant was mixed with deionized water $(5 \mathrm{~mL})$. Then, $1 \mathrm{~mL}$ of ferric chloride $(0.1 \%)$ was added to the solution and the absorbance was measured at $700 \mathrm{~nm}$ in a spectrometer. BHT was used as standard reference.

\subsection{Phenolic Compounds Analysis by HPLC}

Twenty phenolic standard compounds such as chlorogenic acid, gallic acid, (+)-catechin, homogentisic acid, protocatechuic acid, (-)-epicathecin, (-)-epigallocathecin gallate, caffeic acid, vanillin, rutin hydrate, $p$-coumaric acid, ferulic acid, myricetin, naringin, resveratrol, quercetin, naringenin, kaempferol, fomononetin, and biochanin-A were obtained from Sigma-Aldrich (St. Louis, MO, USA). We prepared mushroom extract for phenolic compound analysis according to the method of Im et al. [51]. Alliance ${ }^{\circledR}$ HPLC system 2695 (Waters, Milford, MA, USA) was used for the analysis of phenolic compound constituents of the mushroom extract. Reverse phase $\mathrm{C}_{18}$ column (XSELECT $\mathrm{CSH}^{\mathrm{TM}}, 150 \mathrm{~mm} \times 4.6 \mathrm{~mm} \times 3.5 \mu \mathrm{m}$ ) was used for separation at $40{ }^{\circ} \mathrm{C}$. The injection volume was $20 \mu \mathrm{L}$ and the mobile phase consisted of solvent A $(0.85 \%$ phosphoric acid) and solvent B (acetonitrile). The flow rate was $0.5 \mathrm{~mL} / \mathrm{min}$. The gradient employed solvent $\mathrm{A}(100 \%)$, then was adjusted to solvent A (93\%) and solvent B (7\%) for $5 \mathrm{~min}, \mathrm{~A}(91 \%) / \mathrm{B}(9 \%)$ for $10 \mathrm{~min}, \mathrm{~A}(85 \%) / \mathrm{B}(15 \%)$ for $15 \mathrm{~min}$, A $(78 \%) / B(22 \%)$ for $30 \mathrm{~min}$, A (75\%)/B (25\%) for $40 \mathrm{~min}, \mathrm{~A}(62 \%) / \mathrm{B}(38 \%)$ for $45 \mathrm{~min}$, and solvent B (100\%) for $60 \mathrm{~min}$. The running time was $65 \mathrm{~min}$. The identification of phenolic compounds present in the extracts were determined by photodiode array detector (Waters 2988) at $280 \mathrm{~nm}$ by comparing retention times to those of the authentic standard references.

\subsection{Anti-Diabetic Assay}

\subsection{1. $\alpha$-Amylase Inhibition}

The $\alpha$-amylase inhibitory activity was performed by the method as described by Tadera et al. [52] with minor modification. Two hundred $\mu \mathrm{L}$ of varying concentration of extracts $(0.125-2.0 \mathrm{mg} / \mathrm{mL})$ were prepared in $20 \mathrm{mM}$, pH 6.9 phosphate buffer and then mixed with $200 \mu \mathrm{L}$ of porcine pancreatic $\alpha$-amylase $(0.5 \mathrm{mg} / \mathrm{mL})$ and incubated at $25^{\circ} \mathrm{C}$ for $10 \mathrm{~min}$, and then $200 \mu \mathrm{L}$ of starch solution (1\%) was added and kept at $25^{\circ} \mathrm{C}$ for $30 \mathrm{~min}$. The reaction was stopped by adding $1.0 \mathrm{~mL}$ of dinitrosalicylic acid reagent (1.0 g of 3.5-dinitrosalicylic acid in $20 \mathrm{~mL}$ of $2 \mathrm{M} \mathrm{NaOH}+50 \mathrm{~mL}$ distilled water $+30 \mathrm{~g}$ potassium sodium tartrate tetrahydrate). Then, the mixture was dissolved in distilled water to make a total 
volume of $100 \mathrm{~mL}$, and incubated in a water bath $\left(100^{\circ} \mathrm{C}\right)$ for $5 \mathrm{~min}$ and cooled to room temperature. The reaction mixture was measured at $540 \mathrm{~nm}$ with a UV-Vis spectrophotometer. The $\alpha$-amylase inhibitory activity was calculated using the following formula:

$$
\text { Percent Inhibition }=\left[\left(\mathrm{A}_{\mathrm{c}}-\mathrm{A}_{\mathrm{s}}\right) / \mathrm{A}_{\mathrm{c}}\right] \times 100
$$

where $A_{c}$ is the absorbance of the control reaction (containing all reagents except the test compound) and $A_{S}$ is the absorbance of the test compound. Acarbose was used for the standard reference.

\subsection{2. $\alpha$-Glucosidase Inhibition}

One-hundred $\mu \mathrm{L}$ aliquots of varying extract concentrations $(0.125,0.25,0.5,1.0$ and $2.0 \mathrm{mg} / \mathrm{mL})$ were prepared in $100 \mathrm{mM}$ phosphate buffer $(\mathrm{pH}$ 6.9) and $100 \mu \mathrm{L}$ of $1.0 \mathrm{U} / \mathrm{mL} \alpha$-glucosidase enzyme solution were mixed and kept at $37^{\circ} \mathrm{C}$ for $10 \mathrm{~min}$. Then, $100 \mu \mathrm{L}$ of $5 \mathrm{mM}$-nitrophenyl- $\alpha$ D-glucopyranoside solution was added and the reaction mixture was incubated at $37^{\circ} \mathrm{C}$ for $10 \mathrm{~min}$. Then, $20 \mu \mathrm{L}$ of the mixture was diluted into $1.0 \mathrm{~mL}$ of deionized distilled water. The absorbance was measured at $405 \mathrm{~nm}$ by a UV-Vis spectrophotometer [52]. The $\alpha$-glucosidase inhibitory activity was calculated using the formula (3).

\subsection{Anti-Dementia Assay}

\subsubsection{Anti-Acetycholinesterase Activity}

Acetylcholinesterase inhibitory activity was determined by a slight modification of the method described by Orhan et al. [53]. Electric eel AChE (Type-VI-S, Sigma, C3389-500UN) was used as the enzyme source, while acetylthiocholine iodide was employed as the substrate for the reaction. The acetylcholinesterase activity was measured using 5,5-dithio-bis(2-nitrobenzoic) acid (DTNB). In brief, $120 \mu \mathrm{L}$ of $100 \mathrm{mM}$ sodium phosphate buffer ( $\mathrm{pH} 8.0$ ), $30 \mu \mathrm{L}$ of sample solution dissolved in methanol at various mushroom concentration of extracts $(0.063-1.0 \mathrm{mg} / \mathrm{mL})$ and $30 \mu \mathrm{L}$ of AChE ( $3 \mathrm{U} / \mathrm{mL}$ ) were added and incubated at $25{ }^{\circ} \mathrm{C}$ for $30 \mathrm{~min}$, and then $10 \mu \mathrm{L}$ of DTNB $(0.5 \mathrm{mM})$ was supplemented. The reaction was started by adding $10 \mu \mathrm{L}$ acetylthiocholine iodide $(0.71 \mathrm{mM})$. The hydrolysis of acetylthiocholine iodide was monitored at $412 \mathrm{~nm}$ in a 96-well microplate reader (SpectraMax 340PC, Sunnyvale, CA, USA). The percentage of AChE inhibition was calculated by comparing the sample reaction rates respective to the control (without sample) by the formula:

$$
\% \text { inhibition activity of acetylcholinesterase }=\left[\left(\mathrm{A}_{\mathrm{c}}-\mathrm{A}_{\mathrm{s}}\right) / \mathrm{A}_{\mathrm{c}}\right] \times 100
$$

where $A_{c}$ is the enzyme activity without a test sample and $A_{S}$ is the enzyme activity with a test sample). Galanthamine was used for the standard reference.

\subsubsection{Anti-Butyrylcholinesterase Activity}

The inhibition effect of butyrylcholinesterase was determined by the method of Orhan et al. [53] with minor modification. Horse serum BChE (Sigma, C1057-1KU) was used as the enzyme source, while butyrylcholine iodide was employed as the substrate. DTNB was used to measure activity of butyrylcholinesterase. In brief, $120 \mu \mathrm{L}$ of $100 \mathrm{mM}$ sodium phosphate buffer (pH 8.0), $30 \mu \mathrm{L}$ of sample solution dissolved in methanol with various mushroom extract concentrations $(0.063-1.0 \mathrm{mg} / \mathrm{mL})$ and $30 \mu \mathrm{L}$ of $\mathrm{BChE}(0.35 \mathrm{U} / \mathrm{mL})$ were added and incubated at $25^{\circ} \mathrm{C}$ for $30 \mathrm{~min}$, then $10 \mu \mathrm{L}$ of $0.5 \mathrm{mM}$ DTNB was supplemented. Then, the reaction was started by adding $10 \mu \mathrm{L}$ of butyrylcholine iodide $(0.2 \mathrm{mM})$. The hydrolysis of butyrylcholine iodide was monitored at $412 \mathrm{~nm}$ in a 96 -well microplate reader (SpectraMax 340PC). Percent inhibition of BChE was calculated by comparing the reaction rates of samples relative to the control (without sample) using the formula:

$$
\% \text { butyrylcholinesterase inhibitory activity }=\left[\left(\mathrm{A}_{\mathrm{C}}-\mathrm{A}_{\mathrm{S}}\right) / \mathrm{A}_{\mathrm{C}}\right] \times 100
$$


where $A_{C}$ is the enzyme activity without a test sample and $A_{S}$ is the enzyme activity with a test sample. Galanthamine was used for the standard reference.

\subsubsection{Glutamate-Induced Cytotoxicity}

Cytotoxicity induced by glutamate on PC-12 cell line was determined by modifying the method of Ma et al. [54]. PC-12 cells were seeded in a 96-well microplate at a density of $1 \times 10^{5}$ cells/well. The cell line was cultured for $24 \mathrm{~h}$, and the medium was then changed to contain $10 \mathrm{mM}$ glutamate. After $12 \mathrm{~h}$ of incubation, the cells were treated with varying mushroom extract concentrations $(5,10,20,40$, and $100 \mu \mathrm{g} / \mathrm{mL})$ and cultured for $24 \mathrm{~h}$. After addition of $10 \mu \mathrm{L}$ of 3-(4,5-dimethylthiazol-2-yl)-2,5-diphenyltetrazolium bromide (MTT; $5 \mathrm{mg} / \mathrm{mL}$ ) to each well, the cells were incubated for an additional $4 \mathrm{~h}$ and the supernatant removed. The resulting purple formazan crystals were dissolved in $200 \mu \mathrm{L}$ of dimethyl sulfoxide (DMSO) and the absorbance was measured at $570 \mathrm{~nm}$ in a microplate reader.

\subsection{Anti-Inflammatory Activities}

\subsubsection{Inhibitory Effect on NO Production}

The inhibitory effect of the ME and HWE on the production of NO was determined by the method of Choi et al. [55]. RAW 264.7 macrophage cells were plated into 96-well plates $\left(5 \times 10^{5}\right.$ cells / well) and incubated for overnight at $37^{\circ} \mathrm{C}$ with $5 \%$ atmospheric $\mathrm{CO}_{2}$. Then, the medium was replaced by fresh medium $(0.2 \mathrm{~mL})$ and incubated for $60 \mathrm{~min}$. Then, LPS $(1 \mu \mathrm{g} / \mathrm{mL})$ was added to the culture medium and incubated for $24 \mathrm{~h}$ with or without various mushroom extract concentrations $(0.5,1.0$, and $2.0 \mu \mathrm{g} / \mathrm{mL}$ ). Fifty $\mu \mathrm{L}$ of supernatant was collected and used in the NO analysis.

The accumulation of NO in the medium by RAW 264.7 cells was investigated by the Griess assay [35]. Briefly, $50 \mu \mathrm{g}$ of cell culture medium was mixed with $50 \mu \mathrm{g}$ of Griess reagent (equal volume of $1 \%$ sulfanilamide in $0.1 \%$ naphthylethylenediamide- $\mathrm{HCl}$ and $5 \%$ phosphoric acid $(v / v)$ ). The reaction mixture was left to incubate at $25^{\circ} \mathrm{C}$ for $30 \mathrm{~min}$. The absorbance was measured by a microplate reader at $540 \mathrm{~nm}$, and the NO concentration was determined by sodium nitrite solution as standard concentration.

\subsubsection{Western Blot Analysis}

The Western blot analysis of the ME was performed by the method described by Coruzzi et al. [56]. RAW 264.7 macrophage cells $\left(5 \times 10^{5}\right.$ cells / well) were seeded in 98-well culture plates and treated with LPS alone or LPS $(1 \mu \mathrm{g} / \mathrm{mL})$ with various mushroom extract concentrations $(0,0.5,1.0$, and $2.0 \mathrm{mg} / \mathrm{mL})$ and incubated for $24 \mathrm{~h}$. Then, the cells were washed twice with ice-cold phosphate buffered saline ( $\mathrm{pH}$ 8.0) and lysed in $250 \mu \mathrm{L}$ of ice-cold buffer containing $20 \mathrm{mM}$ Tris- $\mathrm{HCl}$ (pH 7.5), 1\% Triton X-100, $137 \mathrm{mM} \mathrm{NaCl}, 2 \mathrm{mM}$ ethylenediaminetetraacetic acid (EDTA), $1 \mathrm{mM}$ sodium orthovanadate, $2 \mathrm{mM}$ sodium pyrophosphate, $1 \mathrm{mM}$ phenylmethylsulfonyl fluoride, $1 \mu \mathrm{g} / \mathrm{mL}$ leupeptin, $62.5 \mathrm{mM}$ Tris ( $\mathrm{pH}$ 6.8), 2\% sodium dodecyl sulphate (SDS), 10\% glycerol, 5\% 2-mercaptoethanol, and protease inhibitors. The cell lysates were centrifuged at $10,000 \times \mathrm{g}$ for $10 \mathrm{~min}$ at $4{ }^{\circ} \mathrm{C}$. Total cellular proteins from supernatants were separated by $8 \%$ SDS-polyacrylamide gel electrophoresis and transferred onto a polyvinylidene difluoride (PVDF) membrane in $25 \mathrm{mM}$ Tris, 20\% methanol, and $192 \mathrm{mM}$ glycine. The membranes were blocked with non-fat milk (5\%) dissolved in tris-buffered saline (TBS) containing $0.1 \%$ Tween-20 (TTBS) at $4{ }^{\circ} \mathrm{C}$ for $1 \mathrm{~h}$. After blocking, membranes were incubated overnight at $4{ }^{\circ} \mathrm{C}$ and then incubated at $25^{\circ} \mathrm{C}$ with $0.5 \mathrm{~g} / \mathrm{mL}$ anti-mouse iNOS antibodies (BD Biosciences, San Diego, CA, USA) for $2 \mathrm{~h}$. The blotted membranes were washed and incubated with peroxidase-conjugated goat anti-mouse immunoglobulin G (IgG) in TTBS containing 5\% non-fat milk for $1 \mathrm{~h}$. Then, the blots were washed in TTBS three times and the iNOS protein expression was detected by the Amersham ECL Prime Western blotting detection system (GE Healthcare Life Sciences, Buckinghamshire, UK). 


\subsubsection{Carrageenan-Induced Paw Edema}

To determine the in vivo inflammation inhibitory of the T. pubescens fruiting body extracts, carrageenan-induced rat hind paw edema assay was performed [57]. Six-week-old rats were divided into five groups (each group consisted of five rats). Each group of rats was administered $50 \mu \mathrm{L}$ of saline mixed with various concentrations of methanol extract $(5,15$, and $50 \mathrm{mg} / \mathrm{kg}$ per body weight). Then, $30 \mathrm{~min}$ after the administration of the saline and the methanol extracts, $0.1 \mathrm{~mL}$ of $1 \%$ carrageenan was administered onto the subcutaneous surface of the right hind paw. The paw volumes were measured just before carrageenan injection (time 0 ), and 2, 4, and $6 \mathrm{~h}$ after carrageenan injection with a pletismometer (MK-101P, Tokyo, Japan). The increase in paw volume was measured as the difference in paw volume at " $0 \mathrm{~h}$ " and paw volume at respective hours. The inhibition of inflammation was assessed by the increase of paw volumes, calculated using the following formula.

$$
\% \text { increase of paw volume }(\% \mathrm{I})=\left[\left(\mathrm{V}_{\mathrm{t}}-\mathrm{V}_{\mathrm{o}}\right) / \mathrm{V}_{\mathrm{o}}\right] \times 100
$$

where $V_{t}$ represents the final paw volume and $V_{o}$ represents the initial volume of each rat.

\subsection{Statistical Analysis}

All data were expressed as mean \pm standard deviations (SD) and SPSS V.13 (SPSS Inc., Chiago, IL, USA) was used for statistical analysis. One-way analysis of variance followed by Tukey multiple comparisons were used to compare means between groups. Differences between means at the 5\% $(p \leqslant 0.05)$ level were considered statistically significant.

\section{Conclusions}

The antioxidant, anti-diabetes, anti-dementia, and inflammation inhibitory activities of the methanol and hot water extracts of T. pubescens fruiting bodies were studied, and 11 phenolic compounds were discovered in the extracts. The in vitro antioxidant, anti-diabetes, anti-dementia, and anti-inflammatory effects of the mushroom were verified by inhibitory activity on $\alpha$-amylase, $\alpha$-glucosidase, acetyl- and butyryl-cholinesterase, the production of $\mathrm{NO}$, the expression of iNOS, and in vivo carrageenan-induced rat paw edema. Therefore, it is concluded that T. pubescens fruiting bodies possess good natural antioxidant, anti-diabetes, anti-dementia, and inflammation inhibitory sources.

Acknowledgments: This study was supported by research grant from Incheon National University in 2014.

Author Contributions: K.H.I. and J.C. designed research; T.K.N. performed research and analyzed data; T.S.L. wrote the paper. All authors read and approved the final manuscript.

Conflicts of Interest: The authors declare no conflict of interest.

\section{References}

1. Forbes-Hernández, T.Y.; Giampieri, F.; Gasparrini, M.; Mazzoni, L.; Quiles, J.L.; Alvarez-Suarez, J.M.; Battino, M. The effects of bioactive compounds from plant foods on mitochondrial function: A focus on apoptotic mechanisms. Food Chem. Toxicol. 2014, 68, 154-182. [CrossRef] [PubMed]

2. Panicka, K.S.; Anderson, R.A. Effect of polyphenols on oxidative stress and mitochondrial dysfunction in neuronal death and brain edema in cerebral ischemia. Int. J. Mol. Sci. 2011, 12, 8181-8207. [CrossRef] [PubMed]

3. Giampieri, F.; Avarez-Suarez, J.M.; Mazzoni, L.; Forbes-Hernandez, T.Y.; Gasparrini, M.; Gonzàlez-Paramàs, A.M.; Santos-Buelga, C.; Quiles, J.L.; Bompadre, S.; Mezzetti, B.; et al. Polyphenol-rich strawberry extract protects human dermal fibroblasts against hydrogen peroxide oxidative damage and improves mitochondrial functionality. Molecules 2014, 19, 7798-7816. [CrossRef] [PubMed]

4. Jeena, G.S.; Punecha, H.; Prakash, O.; Chandra, M.; Kushwaha, K.P.S. Study on in vitro antioxidant potential of some cultivated Pleurotus species (Oyster mushroom). Indian J. Nat. Resour. 2014, 5, 56-61. 
5. Yildiz, O.; Can, Z.; Laghari, A.Q.; Sahin, H.; Malkoc, M. Wild edible mushrooms as a natural source of phenolics and antioxidants. J. Food Biochem. 2015, 39, 148-154. [CrossRef]

6. Patti, M.E.; Corvera, S. The role of mitochondria in the pathogenesis of type 2 diabetes. Endocr. Rev. 2010, 31, 364-395. [CrossRef] [PubMed]

7. Nathan, D.M.; Buse, J.B.; Davidson, M.B.; Ferrannini, E.; Holman, R.R.; Sherwin, R.; Zinman, B. Medical management of hyperglycemia in type 2 diabetes: A consensus algorithm for the initiation and adjustment of therapy. Diabetes Care 2009, 32, 193-203. [CrossRef] [PubMed]

8. Thompson, P.A.; Wright, D.E.; Counsell, C.E.; Zajicek, J. Statistical analysis, trial design and duration in Alzheimer's disease clinical trials: A review. Int. Psychogeriatr. 2012, 24, 689-697. [CrossRef] [PubMed]

9. Guo, C.; Sun, L.; Chen, X.; Zhang, D. Oxidative stress, mitochondrial damage and neurodegenerative diseases. Neural Regen. Res. 2013, 8, 2003-2014. [PubMed]

10. Colovic, M.B.; Krstic, D.Z.; Lazarevic-Pasti, T.D.; Bondzic, A.M.; Vasic, V.M. Acetylcholinesterase inhibitors: Pharmacology and toxicology. Curr. Neuropharmacol. 2013, 11, 315-335. [CrossRef] [PubMed]

11. Moro, C.; Palacios, I.; Lozano, M.; D’Arrigo, M.; Guillamón, E.; Villares, A.; Martínez, J.A.; García-Lafuente, A. Anti-inflammatory activity of methanolic extracts from edible mushrooms in LPS activated RAW 264.7 macrophages. Food Chem. 2012, 130, 350-355. [CrossRef]

12. Edwards, T. Inflammation, pain, and chronic disease: An integrative approach to treatment and prevention. Altern. Ther. Health Med. 2005, 11, 20-27. [PubMed]

13. Lopez-Armada, M.; Riveiro-Naveira, R.R.; Vaamonde-Garcia, C.; Valcarcel-Ares, M.N. Mitochondrial dysfunction and the inflammatory response. Mitochondrion 2013, 13, 106-118. [CrossRef] [PubMed]

14. Ong, C.K.S.; Lirk, K.; Tan, C.H.; Seymour, R.A. An evidence-based update on nonsteroidal anti-inflammatory drugs. Clin. Med. Res. 2007, 5, 19-34. [CrossRef] [PubMed]

15. Park, W.H.; Lee, H.D. Illustrated Book of Korean Medicinal Mushrooms; Kyo-Hak Publishing Co. Ltd.: Seoul, Korea, 2003.

16. Liew, G.M.; Khong, H.Y.; Kutoi, C.J. phytochemical screening, antimicrobial and antioxidant activities of selected fungi from Mount Singai, Sarawak, Malaysia. Int. J. Res. Stud. Biosci. 2015, 3, 191-197.

17. Si, J.; Cui, B.K. Study of the physiological characteristics of the medicinal mushroom Trametes pubescens (higher basidiomycetes) during the laccase-producing process. Int. J. Med. Mushrooms 2013, 15, 199-210. [CrossRef] [PubMed]

18. Sumathy, R.; Ajesh, T.P.; Kumuthakalavalli, P. Dpph free scavenging activity and total phenolic content of three species of oyster mushrooms. Indian J. Appl. Res. 2013, 3, 1-3. [CrossRef]

19. Mau, J.L.; Lin, H.C.; Song, S.F. Antioxidant properties of several specialty mushrooms. Food Res. Int. 2002, 35, 519-526. [CrossRef]

20. Sarikurkcu, C.; Tepe, B.; Semiz, D.K.; Solak, M.H. Evaluation of metal concentration and antioxidant activity of three edible mushrooms from Mugla, Turkey. Food Chem. Toxicol. 2010, 48, 1230-1233. [CrossRef] [PubMed]

21. Lin, W.Y.; Yang, M.J.; Hung, L.T.; Lin, L.C. Antioxidant properties of methanol extract of a new commercial gelatinous mushrooms (white variety of Auricularia fuscosuccinea) of Taiwan. Afr. J. Biotechnol. 2013, 12, 6210-6221.

22. Singh, N.; Rajini, P.S. Free radical scavenging activity of an aqueous extract of potato peel. Food Chem. 2004, 85, 611-616. [CrossRef]

23. Lee, Y.L.; Huang, G.W.; Liang, Z.C.; Mau, J.L. Antioxidant properties of three extracts from Pleurotus citrinopileatus. LWT Food Sci. Technol. 2007, 40, 823-833. [CrossRef]

24. Lee, Y.L.; Huang, M.T.; Yen, Z.C.; Mau, J.L. Antioxidant properties of various extracts from Hypsizigus marmoreus. Food Chem. 2007, 104, 1-9. [CrossRef]

25. Kim, M.Y.; Seguin, P.; Ahn, J.K.; Kim, J.J.; Chun, S.C.; Kim, E.H.; Seo, S.H.; Kang, E.Y.; Kim, S.L.; Park, Y.J.; et al. Phenolic compound concentration and antioxidant activities of edible and medicinal mushrooms from Korea. J. Agric. Food Chem. 2008, 56, 7265-7270. [CrossRef] [PubMed]

26. Prochazkova, D.; Bousova, L.; Wilhelmova, H. Antioxidant and prooxidant properties of flavonoid. Fitoterapia 2011, 82, 513-523. [CrossRef] [PubMed]

27. Skrovankova, S.; Sumczynski, D.; Mlcek, J.; Jurikova, T.; Sochor, J. Bioactive compounds and antioxidant activity in different types of berries. Int. J. Mol. Sci. 2015, 16, 24673-24706. [CrossRef] [PubMed] 
28. Walter, M.; Marchesan, E. Phenolic compounds and antioxidant activity of rice. Braz. Arch. Biol. Technol. 2011, 54, 371-377. [CrossRef]

29. Zhao, M.; Yang, B.; Wang, J.; Li, B.; Jiang, Y. Identification of the major flavonoids from pericarp tissues of lychee fruit in relation to their antioxidant activities. Food Chem. 2006, 98, 539-544. [CrossRef]

30. Santhoshkumar, S.; Nagarajan, N. In vitro antioxidant and antidiabetic activity of methanol extract of wild' mushroom Ganoderma lucidum (Curtis) P. Karst. Int. J. Biosci. Nanosci. 2014, 1, 77-85.

31. Pandimeena, M.; Prabu, M.; Sumath, R.; Kumuthakalavalli, R. Evaluation of phytochemicals and in vitro anti-inflammatory, anti-diabetic activity of the white oyster mushroom, Pleurotus florida. Int. Res. J. Pharmaceut. Appl. Sci. 2015, 5, 16-21.

32. Agarwal, A.A.; Jadhav, P.R.; Deshmukh, Y.A. Prescribing pattern and efficacy of anti-diabetic drugs in maintaining optimal glycemic levels in diabetic patients. J. Basic Clin. Pharm. 2014, 5, 79-83. [CrossRef] [PubMed]

33. Yin, Z.; Zhang, W.; Feng, F.; Zhang, Y.; Kang, W. $\alpha$-Glucosidase inhibitors isolated from medicinal plants. Food Sci. Human Wellness 2014, 3, 136-174. [CrossRef]

34. Su, C.H.; Lu, T.M.; Lai, M.N.; Ng, L.T. Inhibitory effects of medicinal mushrooms on $\alpha$-amylase and $\alpha$-glucosidase -enzymes related to hyperglycemia. Food Func. 2013, 4, 644-646. [CrossRef] [PubMed]

35. Szwajgier, D. Anticholinesterase activities of selected polyphenols-A short report. Pol. J. Food Nutr. Sci. 2013, 64, 59-64. [CrossRef]

36. Ahmad, W.; Ahmad, B.; Ahmad, M.; Iqbal, Z.; Nisar, M.; Ahmad, M. In vitro inhibition of acetylcholinesterase, butyrylcholinesterase and lipoxygenase by crude extract of Myricaria elegans Royle. J. Biol. Sci. 2003, 11, 1046-1049.

37. Orhan, I.; Kartal, M.; Tosun, F.; Sener, B. Screening of various phenolic acids and flavonoid derivatives for their anticholinesterase potential. Z. Naturforschung C 2007, 62, 829-832.

38. Cong, L.; Cao, C.; Cheng, Y.; Qin, X.Y. Green tea polyphenols attenuated glutamate excitotoxicity via antioxidative and antiapoptotic pathway in the primary cultured cortical neurons. Oxid. Med. Cell. Longev. 2016. [CrossRef] [PubMed]

39. Lee, J.H.; Song, D.K.; Jung, C.H.; Shin, D.H.; Park, J.; Kwon, T.K.; Jang, B.C.; Mun, K.C.; Kim, S.P.; Suh, S.I.; et al. (-)-Epigallocatechin gallate attenuates glutamate-induced cytotoxicity via intracellular $\mathrm{Ca}^{2+}$ modulation in PC12 cells. Clin. Exp. Pharmacol. Physiol. 2004, 31, 530-536. [CrossRef] [PubMed]

40. Tan, J.W.; Tham, C.L.; Isaf, D.A.; Lee, S.H.; Kim, M.K. Neuroprotective effects of biochanin A against glutamate-induced cytotoxicity in PC12 cells via apoptosis inhibition. Neurochem. Res. 2013, 38, 512-518. [CrossRef] [PubMed]

41. Pacher, P.; Bechman, J.S.; Laudit, L. Nitric oxide and peroxynitrite in health and disease. Physiol. Rev. 2007, 87, 315-424. [CrossRef] [PubMed]

42. Song, Y.S.; Kim, S.H.; Sa, J.H.; Jin, C.B.; Lim, C.J.; Park, E.H. Anti-angiogenic and inhibitory activity on inducible nitric oxide production of the mushroom Ganoderma lucidum. J. Ethnopharmacol. 2004, 90, 17-20. [CrossRef] [PubMed]

43. Park, Y.M.; Won, J.; Kim, J.H.; Choi, Y.H.; Park, W.; Park, H.J.; Lee, K.T. In vivo and in vitro anti-inflammatory and anti-nociceptive effects of the methanol extract of Inonotus obliquus. J. Ethnopharmacol. 2005, 101, 120-128. [CrossRef] [PubMed]

44. Chen, J.N.; Mejia, E.G.; Wu, J.W.B. Inhibitory effect of a glycoprotein isolated from golden oyster mushroom (Pleurotus citrinopileatus) on the lipopolysaccharide-induced inflammatory reaction in Raw 264.7 macrophage. J. Agric. Food Chem. 2011, 59, 7092-7097. [CrossRef] [PubMed]

45. Taofiq, O.; Calhelha, R.C.; Heleno, S.; Barros, L.; Martins, A.; Santos-Buelga, C.; Queiroz, M.J.R.P.; Ferreira, I.C.F.R. The contribution of phenolic acids to the anti-inflammatory activity of mushrooms: Screening in phenolic extracts, individual parent molecules and synthesized glucuronated and methylated derivatives. Food Res. Int. 2015, 76, 821-827. [CrossRef]

46. Wu, S.J.; Tsai, J.Y.; Lai, M.N.; Ng, L.T. Armillariella mellea shows anti-inflammatory activity by inhibiting the expression of NO, iNOS, COX-2 and cytokines in THP-1 cells. Am. J. Chin. Med. 2007, 35, 507-516. [CrossRef] [PubMed]

47. Posadas, I.; Bucci, M.; Roviezzo, F.; Rossi, A.; Parente, L.; Sautebin, L.; Cirino, G. Carrageenan-induced mouse paw oedema is biphasic, age-weight dependent and displays differential nitric oxide cyclooxygenase-2 expression. Br. J. Pharmacol. 2004, 142, 331-338. [CrossRef] [PubMed] 
48. Galvez, M.; Martin-Cordero, C.; Houghton, P.J.; Ayuso, M.J. Antioxidant activity of Plantago bellardii All. Phytother. Res. 2005, 19, 1074-1076. [CrossRef] [PubMed]

49. Sowndhararajan, K.; Kang, S.C. Free radical scavenging activity from different extracts of leaves of Bauhinia vahlii Wight \& Arn. Saudi J. Biol. Sci. 2013, 20, 319-325. [PubMed]

50. Gulcin, I.; Buyukokuroglu, M.E.; Oktay, M.; Kufrevioglu, I.O. Antioxidant and analgesic activities of turpentine of Pinus nigraarn. Subsp. Pallsiana (Lamb.) Holmboe. J. Ethnopharmacol. 2003, 86, 51-58. [CrossRef]

51. Im, K.H.; Nguyen, T.K.; Shin, D.B.; Lee, K.R.; Lee, T.S. Appraisal of antioxidant and anti-inflammatory activities of various extracts from the fruiting bodies of Pleurotus florida. Molecules 2014, 19, 3310-3326. [CrossRef] [PubMed]

52. Tadera, K.; Minami, Y.; Takamatsu, K.; Matsuoka, T. Inhibition of $\alpha$-glucosidase and $\alpha$-amylase by flavonoids. J. Nutr. Sci. Vitaminol. 2006, 52, 149-153. [CrossRef] [PubMed]

53. Orhan, I.; Sener, B.; Choudhary, M.I.; Khalid, A. Acetylcholinesterase and butyrylcholinesterase inhibitory activity of some Turkish medicinal plants. J. Ethnopharmacol. 2004, 91, 57-60. [CrossRef] [PubMed]

54. Ma, S.; Liu, H.; Jiao, H.; Wang, L.; Chen, L.; Liang, J.; Zhao, M.; Zhang, X. Neuroprotective effect of ginkgolide $\mathrm{K}$ on glutamate-induced cytotoxicity in PC 12 cells via inhibition of ROS generation and $\mathrm{Ca}^{2+}$ influx. NeuroToxicology 2012, 33, 59-69. [CrossRef] [PubMed]

55. Choi, J.K.; Cha, D.S.; Lee, Y.J.; Ko, S.H.; Park, H.J.; Lee, S.Y.; Choi, J.H.; Jeon, H. Effects of Vitex rotundifolia on radical scavenging and nitric oxide production. Orient. Pharm. Exp. Med. 2010, 10, 51-58. [CrossRef]

56. Coruzzi, G.; Adami, M.; Guaita, E.; de Esch, I.J.; Leurs, R. Antiinflammatory and antinociceptive effects of the selective histamine H4-receptor antagonists JNJ7777120 and VUF6002 in a rat model of carrageenan-induced acute inflammation. Eur. J. Pharmacol. 2007, 563, 240-244. [CrossRef] [PubMed]

57. Fereidoni, M.; Ahmadiani, A.; Semnanian, S.; Javan, M. An accurate and simple method for measurement of paw oedema. J. Pharmacol. Toxicol. Methods 2000, 43, 11-14. [CrossRef]

Sample Availability: Samples of the dried fruitting bodies powder are available from the authors.

(C) 2016 by the authors; licensee MDPI, Basel, Switzerland. This article is an open access article distributed under the terms and conditions of the Creative Commons Attribution (CC-BY) license (http://creativecommons.org/licenses/by/4.0/). 